\title{
Diversity of galling insects in Styrax pohlii (Styracaceae): edge effect and use as bioindicators
}

\author{
Walter Santos de Araújo ${ }^{1,2 *}$, Genimar Rebouças Julião ${ }^{3}$, Bárbara Araújo Ribeiro ${ }^{2}$, Isadora Portes \\ Abraham Silva ${ }^{2} \&$ Benedito Baptista dos Santos ${ }^{2}$ \\ 1. Pós-Graduação em Ecologia e Evolução, Instituto de Ciências Biológicas, Universidade Federal de Goiás. Campus \\ Samambaia, 74001-970, Goiânia, Goiás, CP 131, Brazil; walterbioaraujo@yahoo.com.br \\ 2. Laboratório de Entomologia, Departamento de Biologia Geral, Instituto de Ciências Biológicas, Universidade \\ Federal de Goiás. Campus Samambaia, 74001-970, Goiânia, Goiás, CP 131, Brazil; barbara.ar.bio@gmail.com, \\ isadoraportes@hotmail.com, bbsantos@icb.ufg.br \\ 3. Instituto Leônidas e Maria Deane, Fiocruz Amazônia. Adrianópolis, 69057-070, Manaus, Amazonas, CP 476, Brazil; \\ grjuliao@gmail.com \\ * Corresponding author
}

Received 25-X-2010. C Corrected 10-III-2011. Accepted 13-IV-2011.

\begin{abstract}
Impacts of forest fragmentation and edge effect on plant-herbivores interactions are relatively unknown, and the relationships between galling insects and their host plants are very susceptible to environmental variations. The goal of our study was to test the edge effect hypothesis for galling insects associated with Styrax pohlii (Styracaceae) host plant. Samplings were conducted at a fragment of semi-deciduous forest in Goiânia, Goiás, Brazil. Thirty host plant individuals (15 at fragment edge and 15 in its interior) were sampled in July of 2007; in each plant, 10 apical branches were collected at the top, middle and bottom crown levels. Our results supported the prediction of greater richness of gall morphotypes in the edge habitat compared with remnant interior. In a similar way, gall abundance and frequency of attacked leaves were also greater in the fragment edge. These findings consequently suggest a positive response of galling insect diversity to edge effect; in the Saint-Hilaire forest, this effect probably operates through the changes in microclimatic conditions of edge habitats, which results in an increased hygrothermal stress, a determinant factor to distribution patterns of galling insects. We also concluded that these organisms could be employed as biological indicators (i) because of their host-specificity, (ii) they are sensitive to changes in plant quality, and (iii) present dissimilar and specific responses to local variation in habitat conditions. Rev. Biol. Trop. 59 (4): 1589-1597. Epub 2011 December 01.
\end{abstract}

Key words: environmental stress, urban fragmentation, microclimatic changes, semi deciduous forest, Cerrado.

The substitution of large areas of forests for human-made landscapes leads to the creation of isolated forest fragments, immersed in a matrix of non-forest areas (Paciencia \& Prado 2004). In the case of Cerrado (Brazilian savannas), habitat fragmentation is the main cause of diversity loss, especially due to the advancement of agriculture and livestock frontiers (Klink \& Machado 2005, Hero \& Ridgway 2006). Besides, fragmentation can expose habitat interior to extreme conditions, making it susceptible to edge effect (Murcia 1995).
Many papers have focused on the influence of edge effect on plants populations, vertebrates and invertebrates in different temperate and tropical vegetation types, especially those which suffered some kind of human action (Laurance et al. 1998, Foggo et al.2001, Christie \& Hochuli 2005, Fonseca \& Joner 2007, Christie et al.2010).

According to Murcia (1995), there are three types of edge effects in forest fragments: abiotic effects, direct biological effects and indirect biological effects. The first one refers 
to climatic and edaphic modifications as a result of the matrix proximity (environment outside to fragment); the second to variation in abundance and species distribution as direct consequence of physical conditions near the edge. Finally, disruption on species interactions, such as predation, competition, parasitism, herbivory, pollination and seeds dispersion by animals is considered the indirect biological effect (Murcia 1995). Small fragments usually are considered as extensive strips of edge, because they can suffer equally the effects of microclimatic changes (Paciencia \& Prado 2004). Despite of fragment size, microclimatic variations seem to be strongly influenced by the distance in relation to fragment periphery (Laurance et al. 2002). Recently, several studies have related edge effect with to herbivory by free life insects (Bolger et al. 2000, Meiners et al.2000, Foggo et al.2001) and galling insects (Julião et al. 2004).

Compared to the gall-forming insects, diversity of free-living insect herbivores seems to be restricted in the Cerrado vegetation (Ribeiro \& Fernandes 2000). In general, sclerophyllous plants developed several adaptations as chemical (phenolic compounds, and lignin) or structural traits (pubescence, fibers, and hardness) which reduce significantly herbivory by free-living insects (Ribeiro et al. 1998, Ribeiro \& Fernandes 2000). However, all these features would be responsible for the evolutionary success of galling insects in such plants, since the action of predators, parasites and pathogens on galling insects could be less effective in the scleromorphic vegetation types (Gonçalves-Alvim \& Fernandes 2001, Fernandes et al.2005). These findings also fit with the nutritional stress hypothesis (Fernandes \& Price 1988), which predicts a greater diversity of gall-forming insects in scleromorphic vegetation and nutritional stressed habitats. Several works agree with this hypothesis, emphasizing its adaptive value for insects (Price et al. 1987, Fernandes \& Price 1988, Fernandes \& Price 1992) and/or comparing different phytophysionomies (Gonçalves-Alvim \& Fernandes
2001, Veldtman \& McGeoch 2003, NievesAldrey et al. 2008).

Gall-forming insects, frequently identified by distinctive morphotypes of the gall structure induced (Stone \& Schönrogge 2003), constitute excellent tools for environmental studies (Julião et al. 2005). Among their characteristics, they are sessile, easily located and strictly associated with its host plant (Mani 1964, Dreger-Jauffret \& Shorthouse 1992), and galls can be potentially used as bioindicators of habitat quality (Moreira et al. 2007, Fernandes et al. 2010). Relationships between galling insects and their host plants are very sensitive to environment alteration, especially those that interfere on physiological features of hosts (Fernandes et al.2005). Furthermore, modification in habitat quality due to the anthropization may change significantly spatial distribution of galls at local scale (Julião et al. 2005).

The edge effect on fragmented landscapes usually results in changes on floristic composition and plant population structure (Nascimento \& Laurance 2006), e.g. increasing of plant mortality (Laurance et al. 1998) and susceptibility to diseases (Christie \& Hochuli 2005). Such features, along with microclimatic variation might favor the increase in herbivore insect populations, herbivory rates (Christie \& Hochuli 2005, Christie et al.2010) and, mainly, galling insect diversity. Edge conditions could give rise to a hydric and nutritionally stressed habitat which would have a greater colonization by galling insects compared to free-feeding herbivores; the formers would be insignificantly affected by desiccation once they spent their lives inside gall structure. Nevertheless, impacts of forest fragmentation and edge effect on plant-herbivores interactions are relatively unknown (Meiners et al. 2000). In this work we test the hypothesis that galling insects richness and abundance are affected by the edges, and that both parameters will be greater in a fragment edge compared to its interior. Such prediction is based on the assumption that host plants which are submitted to a differential microclimatic condition (hygrothermal stress in edge habitat) could be less defended against 
herbivores. Furthermore, we also discuss the employment of insect galls as bioindicators of habitat quality.

\section{MATERIALS AND METHODS}

Study area: The research was carried out in July, 2007, at Saint-Hilaire Forest, a remnant area of mesophile semi-deciduous forest, placed in the campus of Universidade Federal de Goiás in Goiânia (16036'13.16" S - 49¹5'41.58” W), Goiás State, Brazil (Fig. 1; www.googleearth.com, accessed in September/2010). Regional climate is AW type by the Köppen classification, with rainy summers (from October to March) and dry winter (from April to September) (Brandão \& Kravchenko 1997). Saint-Hilaire forest is constituted by three urban forest fragments, summing up an area of 21.14ha (Brandão \& Kravchenko 1997). Samplings were only taken in a $4.85 \mathrm{ha}$ fragment, with irregular quadrilateral shape. This fragment is separated from the others by a 20m strip of deforested area. No substantial differences in the floristic composition were observed among these fragments, since they had composed a unique forest before (Brandão \& Kravchenko 1997).

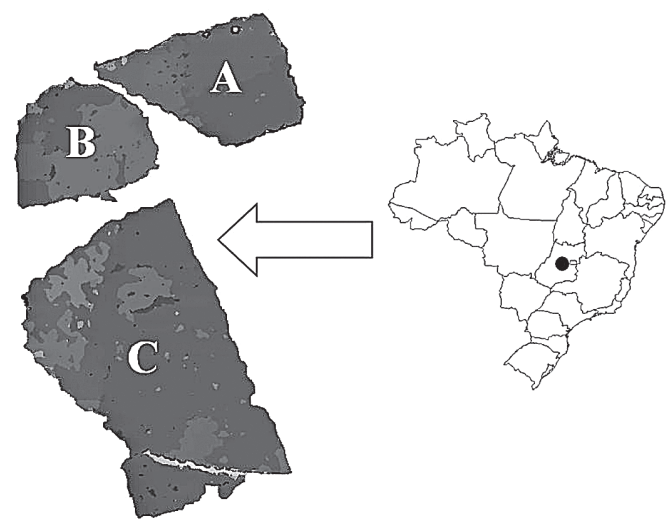

Fig. 1. Fragments that constitute the Saint Hilaire Forest (A, B and C), Universidade Federal de Goiás, in Goiânia, Goiás, Brazil. Sampling was done in the fragment B. (Source: Google Earth, September/2010).
Sampling methodology: Some fragments that constitute Saint-Hilaire forest are impacted by man (Santos et al. 2010), with the presence of cement trails that cross the forest and constant movement of people. To avoid these effects, sampling was made at the less disturbed fragment. In this study, edge habitat was considered as the $50 \mathrm{~m}$ more external strip, which represents about $25 \%$ of the lowest diameter of fragment ( 200 meters). Although no biotic or abiotic measures had been made, we observed that interior of the sampled fragment showed different characteristics such as lower luminosity and temperature, and higher trees than edge habitat. According to Laurance et al. (2002), that is the maximum penetration distance of microclimatic changes in tropical forest fragments. To semi deciduous forests, edge extent has few registers; at instance, fern richness was severely affected in the first $20 \mathrm{~m}$ from boundary (Paciencia \& Prado 2004).

The host plant Styrax pohlii Fritsch (Styracaceae) harbor a great richness of gall morphotypes (Araújo \& Santos 2009, Santos et al. 2010), has arboreal-shrubby habit reaching up to $10 \mathrm{~m}$, and is very common in forest environments (Souza \& Lorenzi 2005). We randomly choose 30 host plant individuals, being 15 at the edge and 15 at the fragment interior; sampled host plants distanced at least four meters from each other. In each individual plant, 10 apical branches were randomly collected at the bottom, middle, and top of the crown. In laboratory, each branch was inspected for insect gall presence, which were morphologically characterized (Table 1) and separated in morphospecies (morphotypes). After this, we estimated gall morphotype richness and abundance, percentage of leaves attacked by galling insects, number of galls per leaf and per individual. Adult insects obtained from the galls were identified in order/family levels with entomological keys and deposited in the reference collection of the Entomology Laboratory (LABENT/UFG).

For all analyses, we previously checked the assumptions of normality and homogeneity of variances. In order to verify possible 
TABLE 1

Morphological description of insect galls associated with host plant Styrax pohlii in the period of July, 2007, in a fragment of semi-deciduous forest in Goiânia, Goiás, Brazil

\begin{tabular}{cccccccc}
$\begin{array}{c}\text { Morpho- } \\
\text { species }\end{array}$ & Organ & Form & Color & Pubescence & Ocurrence & Galling & Figure \\
A & Leaf & Globoid & Brown & Pilose & Isolated & Hymenoptera & Fig. 2A \\
B & Leaf & Globoid (erythrocyte) & Red/Brown & Pilose & Isolated & Cecidomyiidae & Fig. 2B \\
C & Leaf (abaxial) & Globoid & Brown & Glabrous & Isolated & Cecidomyiidae & Fig. 2C \\
D & Leaf & Globoid & Brown & Glabrous & Isolated & Unspecified & Fig. 2D \\
E & Leaf & Conicle & Green & Glabrous & Isolated & Unspecified & Fig. 2E \\
F & Leaf (adaxial) & Discoid & Brown & Glabrous & Isolated & Cecidomyiidae & Fig. 2F \\
G & Stem & Fusiform & Brown & Glabrous & Isolated & Cecidomyiidae & Fig. 2G \\
H & Stem & Globoid & Brown & Glabrous & Isolated & Cecidomyiidae & Fig. 2H \\
\hline
\end{tabular}

differences in gall richness and abundance between interior and edge habitats, we employed the average comparison tests for separate variance estimates ( $t$ test for separate variance). Percentage of leaves attacked by galling insects, number of galls per leaf and per individual was compared between edge and interior habitats by the average comparison tests ( $t$ test). These analyses were done in the programs Bio-Stat 2007 and Statistic 7.1. In the software R, ANOVA two-way were used to test the interaction between factors (habitat vs. morphotypes), in order to better characterize the species-specific response to the habitat.

\section{RESULTS}

Insect gall morphospecies: Overall 8 208 insect galls were recorded and eight distinct morphotypes were found associated with Styrax pohlii host plant. Six morphotypes (7 975 galls) were induced on leaves (Fig. 2 A-F) and 233 gall insects were found on stems, belonging to two gall morphospecies (Fig. 2 G-H). Cecidomyiidae (Diptera) was the main gall inducer and provoked five morphotypes, followed by Hymenoptera (one morphotype). There were two unidentified morphospecies (Table 1).

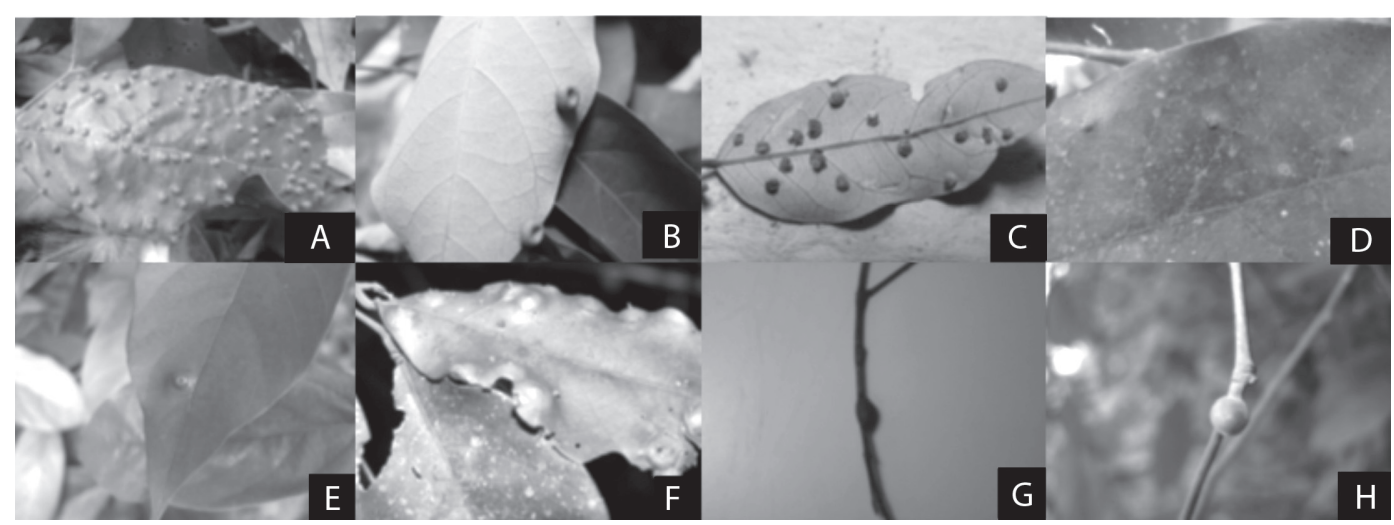

Fig. 2. Morphotypes of galls associated to the host plant Styrax pohlii in a fragment of a mesophile semi-deciduous forest in Goiânia, Goiás, Brazil. 


\section{Comparisons between edge and interior} habitats: Gall richness and abundance associated to $S$. pohlii differed significantly between edge and interior of the fragment $(\mathrm{t}=-3.72$, $\mathrm{n}=30, \mathrm{p}<0.01 ; \mathrm{t}=6.47, \mathrm{n}=30, \mathrm{p}<0.001$, respectively). In general, fragment edge presented a greater richness and abundance of galling insects than its interior (Fig. 3). In the fragment interior was found an average of 3.47 $( \pm 1.41)$ gall morphotypes per individual while these average was $5.07( \pm 0.88)$ morphotypes along the edge.

Similar result was obtained in the number of leaves attacked by galling insects which were greater at the edge habitat than fragment interior $(t=3.79, n=30, p<0.01)$. Percentage of leaves attacked by galling insects in fragment interior was $20.5 \%$, while this value reached $25.1 \%$ in the edge.

The number of galls per leaf did not vary between edge and interior of the fragment $(\mathrm{t}=0.13, \mathrm{n}=30, \mathrm{p}>0.05)$. At average, edge host individuals presented 7.2 galls per leaf, while interior individuals possessed about seven galls per leaf. On the other hand, the number of galls per individual ( $\mathrm{g} / \mathrm{ind}$.) was significantly greater in the edge $(\mathrm{t}=4.64, \mathrm{n}=30, \mathrm{p}<0.01)$ showing $376 \mathrm{~g} / \mathrm{ind}$. against 170 in the interior fragment.

Morphotypes distribution pattern: All gall morphotypes occurred in both fragment habitats (edge and interior); being that most of them occurred in similar proportions in both habitats $(\mathrm{F}=0.43, \mathrm{n}=128, \mathrm{p}>0.05)$. Morphotype $\mathrm{B}$ was the predominant morphospecies in both edge and interior; 14 (93\%) individuals in each habitat presented this morphotype. In the edge, the second most abundant morphotype was $\mathrm{H}$ occurring in 13 (86.6\%), followed by morphotype E, which occurred in $12(80 \%)$ of the host plants (Fig. 4). The proportion of the morphotypes $\mathrm{A}$ and $\mathrm{G}$ varied strongly between habitats $(\mathrm{F}=6.89, \mathrm{n}=27, \mathrm{p}<0.05)$. Morphotype $\mathrm{G}$, which occurred only in one host individual at the edges, was recorded in $13(86.6 \%)$ of host individuals in fragment interior, while the morphotype A occurred only in two plants in the interior and in 11 plants at the edge (Fig. 4).
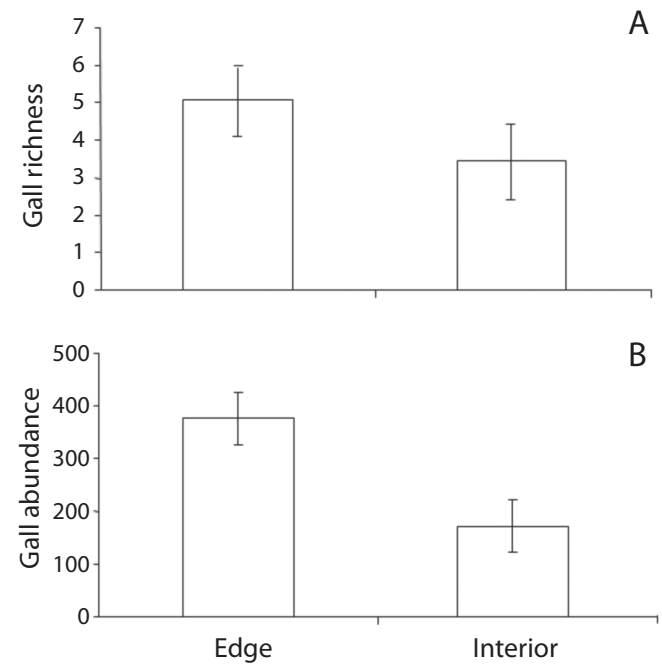

Fig. 3. Richness (A) and abundance (B) of gall morphotypes by individuals of Styrax pohlii at the edge and interior of a fragment of mesophile semi-deciduous forest in Goiânia, Goiás, Brazil.

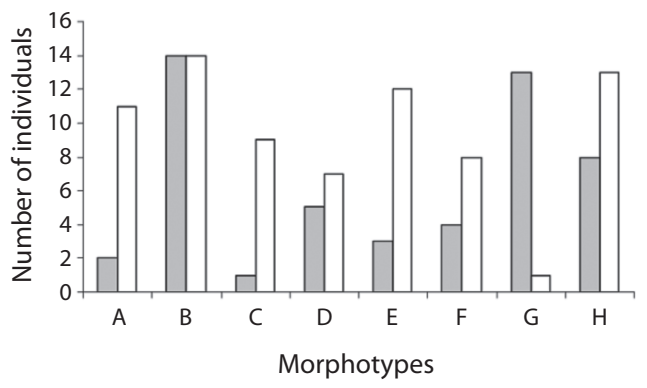

Fig. 4. Number of individuals of Styrax pohlii attacked by the gall morphotypes A to $\mathrm{H}$ (details in Fig. 2) in the interior (gray bars) and edge (white bars) of a fragment of mesophile semi-deciduous forest in Goiânia, Goiás, Brazil.

\section{DISCUSSION}

Richness and abundance of gall morphotypes associated to $S$. pohlii were greater in the Saint-Hilaire edges. Average number of attacked leaves, galls per leaf and galls per individual, were also greater in host plants localized in this habitat. These results suggest that $S$. pohlii hosts localized on edges are more 
prone to galling insect attack, possibly because they are under some level of stress due to edge effect. Stressed plants would be more susceptible to attack by urban insects in anthropic areas, due to alterations in its physiology and herbivore defenses (Fernandes et al. 1995, Christie \& Hochuli 2005, Christie et al. 2010).

Many studies have demonstrated a positive relationship between richness of galling insects and stressed habitats (Fernandes \& Price 1988, Price et al. 1998, GonçalvesAlvim \& Fernandes 2001). Habitats with lower soil fertility (mainly phosphorus, nitrogen, magnesium, potassium and iron) usually present a higher diversity of gall-forming insects, both in scleromorphic and non-scleromorphic vegetations (Gonçalves-Alvim \& Fernandes 2001, Cuevas-Reyes et al. 2004). Carneiro et al. (2005) investigated the diversity of galling insects in Baccharis concinna Barroso (Asteraceae), and also obtained similar results: habitat stress influenced positively galling insect diversity.

Moreover, different insect guilds (such as miners, galling insects, wood, leaf and sapfeeders) may respond to different physiological and morphological changes in its resources/ host plants (Galway et al. 2004). For many insect species, vigor and module size increase the larval performance, by expanding survival and development rates (Price 1991). Thus, vigor and plant stress have been good predictors of galling insects to diversity (White 2009). Edge effect could be an explanation for galling insects diversity patterns in human-made fragments because subsequent stress conditions might affect plant community (Murcia 1995); hence, edge effect could reproduce similar conditions to those found in more xeric habitats, as verified by Fernandes \& Price (1988).

Hydric and nutritional stresses had been related to various changes in plants (Nepomuceno et al. 2001). Stress is, by definition, a deviation from optimum conditions for plant development that induces changes and responses in all functional levels, reversible at first, but which may become permanent (Larcher 2000). Such physiological responses are specific to a hydric deficit, ranging and depend on the severity, nature and during of stress, genotypic traits, and stage of plant development (Nepomuceno et al. 2001). Some modifications are able to maintain plant growth and reproduction in environments with water availability limitations (Larcher 2000). However, increased plants susceptibility to herbivore attack is one of the main consequences of vegetal stress. Shortage of water and nutrients also leads to alterations in the hormonal and physiological status of plants (Larcher 2000), resulting in compromised defense mechanisms against herbivory (Fernandes et al. 1995).

Insect assembly has been extensively adopted in environmental monitoring (Brown 1991, Fernandes et al. 1995). Brown (1997) points that groups utilized for this purpose must be common, biological and taxonomically well understood easily observed and identified, in any place or period. Furthermore, must be diffused and comparable among areas, periods and habitats, sensitive to physical and biological factors, strictly associated to other taxa and resources, and show a predicted reaction before any modification in local habitats. In this context, galling insects could constitute good bioindicators of habitat quality (Fernandes et al. 1995) by presenting many of these characteristics (Julião et al. 2005). They are host-specific, and gall morphology is specific for each inductor (Fernandes et al. 1996, Shorthouse et al. 2005, Espírito-Santo \& Fernandes 2007), and thus compensates the lack of taxonomic resolution; galling insects are very exigent and sensitive to characteristics necessary for survival (Fernandes et al. 1995). Julião et al. (2005) found a heterogeneous distribution of galling insects in two plant species which occur in vegetation of urban biotopes. Galling insect abundance were greater in biotopes less intensively occupied; such result highlight the importance of urban reserves, wastelands, parks, public and private gardens to the maintenance of insect diversity (Julião et al. 2005).

Due to intimate association with its host plants, insect gall studies provide data of great relevance for knowledge of nutritional and 
physiological status of plants and habitats (Fernandes et al. 1995). In a comparative study of forest habitat health, galling community presented a great dissimilarity among primary equatorial forests and early, intermediate and late succession stands; hence, gall-forming insects could be stated as indicators of variations in forest structure and host plant composition, and age of restoration stand (Fernandes et al. 2010). This can be done by monitoring the distribution and the levels of herbivory galling in disturbed habitats and in good conservation state. Although we did not sample galling insect species exclusive to edge or interior habitat, gall morphotypes A had higher abundance at edge, while the morphotype $\mathrm{G}$ was more numerous in the interior of the Saint-Hilaire fragment. Based on these results, we propose that further studies can take in consideration the feasibility of these two gall morphotypes as bioindicators, since the host plant (Styrax pohlii) possess numerous populations in the regions where it occurs (Caiafa \& Martins 2010). Additional studies are also necessary to confirm the obtained pattern of high diversity of galling insect in the edges of fragmented landscapes, and to verify the specificity of these potential indicators to habitats and plant physiological status, aiming to test the galling insect employment as monitoring tool of environment conditions.

\section{ACKNOWLEDGMENTS}

We thank Claudia Scareli-Santos for comments on the manuscript, Postgraduate Program in Ecologia e Evolução of the Universidade Federal de Goiás, CAPES and the Pesquisador Visitante Program (Fiocruz/CNPq, no. 310507/2007-3) for financial support.

\section{RESUMEN}

Los impactos de la fragmentación de los bosques y el efecto de borde sobre las interacciones planta-herbívoros son relativamente desconocidos, y las relaciones entre los insectos inductores de agallas y sus plantas hospederas son muy susceptibles a las variaciones ambientales. El objetivo de nuestro estudio fue probar la hipótesis de efecto de borde en los insectos inductores de agallas asociados con la planta hospedera Styrax pohlii (Styracaceae). Los muestreos se realizaron en un fragmento de bosque semideciduo en Goiânia, Goiás, Brasil. Se tomaron muestras de treinta plantas hospederas (15 en el borde del fragmento y 15 en su interior), en cada planta, 10 ramas apicales fueron recolectadas en la parte superior, media e inferior. Nuestros resultados apoyan la predicción de una mayor riqueza de morfotipos de agallas en el borde del hábitat en comparación con su interior. De manera similar, la abundancia de las agallas y la frecuencia de las hojas atacadas también fueron mayores en el borde del fragmento. Estos resultados sugieren por consiguiente, una respuesta positiva de la diversidad de insectos de agallas al efecto borde, en el bosque de Saint-Hilaire, este efecto probablemente opera a través de los cambios en las condiciones microclimáticas de los hábitats de borde, que se traduce en un aumento de estrés higrotérmico, un factor determinante para los patrones de distribución de estos insectos. En conclusión, sugerimos que estos organismos podrían ser empleados como indicadores biológicos debido a (i) su especificidad del hospedero, (ii) su sensibilidad a los cambios en la calidad de la planta y, (iii) presentar respuestas diferentes y específicas a las variaciones locales de las condiciones del hábitat.

Palabras clave: bioindicadores, Cerrado, estrés ambiental, morfotipos de agallas, fragmentación urbana, cambios microclimáticos, bosque semideciduo.

\section{REFERENCES}

Araújo, W.S. \& B.B. Santos. 2009. Complexidade estrutural e diversidade de insetos galhadores em Styrax pohlii Fritsch (Styracaceae). Bioscience J. 25: 181-184.

Bolger, D.T., A.V. Suarez, K.R. Crooks, S.A. Morrison \& T.J. Case. 2000. Arthropods in urban habitat fragments in Southern California: area, age, and edge effects. Ecol. Appl. 10: 1230-1248.

Brandão, D. \& A. Kravchenko. 1997. A biota do Campus Samambaia: História, situação atual e perspectivas. Cegraf, Goiânia, Goiás, Brasil.

Brown, K.S. 1991. Conservation of Neotropical environments: insects as indicators, p. 349-404. In N.M. Collins \& J.A. Thomas (eds.). The conservation of insects and their habitats. Academic, Royal Entom. Soc. Symposium XV, London, London, England.

Brown, K.S. 1997. Diversity, disturbance, and sustainable use of Neotropical forests: insects as indicators for conservation monitoring. J. Insect Conserv. 1: 25-42. 
Caiafa, A.N. \& F.R. Martins. 2010. Forms of rarity of tree species in the southern Brazilian Atlantic rainforest. Biodivers. Conserv. 19: 2597-2618.

Carneiro, M.A.A., G.W. Fernandes \& O.F.F. Souza. 2005. Convergence in the variation of local and regional galling species richness. Neotr. Ent. 34: 547-543.

Christie, F.J. \& D.F. Hochuli. 2005. Elevated levels of herbivory in urban landscapes: are declines in tree health more than an edge effect? Ecol. Soc. 10: 1-10.

Christie, F.J., C. Gerasimos \& D.F. Hochuli. 2010. Urbanization affects the trophic structure of arboreal arthropod communities. Urban Ecosyst. 13: 169-180.

Cuevas-Reyes, P., M. Quesada, P. Hanson, P. Dirzo \& K. Oyama. 2004. Diversity of gall-inducing insects in a Mexican tropical dry forest: the importance of plant species richness, life-forms, host plant age and plant density. J. Ecol. 92: 707-716.

Dreger-Jauffret, F. \& J.D. Shorthouse. 1992. Diversity of gall-inducing insects and their galls, p. 8-33. In J.D. Shorthouse \& O. Rohfritsch (eds.). Biology of insect-induced galls. Oxford University, New York, New York, USA.

Espírito-Santo, M.M. \& G.W. Fernandes. 2007. How many species of galling insects are there on earth and where they are? Ann. Entomol. Soc. Am. 100: 95-99.

Fernandes, G.W. \& P.W. Price. 1988. Biogeographical gradients in galling species richness: tests of hypotheses. Oecologia 76: 161-167.

Fernandes, G.W. \& P.W. Price. 1992. The adaptive significance of insect gall distribution: survivorship of species in xeric and mesic habitats. Oecologia 90: 14-20.

Fernandes, G.W., A.S. Paula \& R. Loyola. 1995. Distribuição diferencial de insetos galhadores entre habitats e seu possível uso como bioindicadores. Vida Silv. Neotr. 4: 133-139.

Fernandes, G.W., M.A.A. Carneiro, A.C.F. Lara, L.A. Allain, G.I. Andrade, G.R. Julião, T.C. Reis \& I.M Silva. 1996. Galling insects on neotropical species of Baccharis (Asteraceae). Trop. Zool. 9: 315-332.

Fernandes, G.W., S.J. Gonçalves-Alvim \& M.A.A. Carneiro. 2005. Habitat-driven effects on the diversity of gall-inducing insects in the Brazilian cerrado, p. 693-708. In A. Raman, C.W. Schaefer \& T.M. Withers. (eds.). Biology, ecology, and evolution of gall-inducing arthropods. Science, Enfield, New Hampshire, USA.
Fernandes, G.W., E.D. Almada \& M.A.A. Carneiro. 2010. Gall-Inducing Insect Species Richness as Indicators of Forest Age and Health. Environ. Entomol. 39: 1134-1140.

Foggo, A., C.M.P. Ozanne, M.R. Speight \& C. Hambler. 2001. Edge effects and tropical forest canopy invertebrates. Plant Ecol. 153: 347-359.

Fonseca, C.R. \& F. Joner. 2007. Two-sided edge effect studies and the restoration of endangered ecosystems. Restor. Ecol. 15: 613-619.

Galway, K.E., R.P. Duncan, P. Syrett, R.M. Emberson, A.W. Sheppard. 2004. Insect performance and hostplant stress: a review from a biological control perspective, p. 394-399. XI International Symposium on Biological Control of Weeds, Canberra, Federal District, Australia.

Gonçalves-Alvim, S.J. \& G.W. Fernandes. 2001. Biodiversity of galling insects: historical, community and habitat effects in four neotropical savannas. Biodivers. Conserv. 10: 79-98.

Hero, J.M., T. Ridgway. 2006. Declínio global de espécies, p. 53-90. In C.F.D. Rocha, H.G. Bergallo, M.V. Sluys \& M.A.S. Alves. Biologia da Conservação: Essências. Ed. RiMa, São Carlos, São Paulo, Brasil.

Julião, G.R., M.E.C. Amaral, G.W. Fernandes \& E.G. Oliveira. 2004. Edge effect and species-area relationships in the gall-forming insect fauna of natural forest patches in the Brazilian Pantanal. Biodivers. Conserv. 13: 2055-2066.

Julião, G.R., G.W. Fernandes, D. Negreiros, L. Bedê \& R.C. Araújo. 2005. Insetos galhadores associados a duas espécies de plantas invasoras de áreas urbanas e peri-urbanas. Rev. Bras. Ent. 49: 97-106.

Klink, C.A. \& R.B. Machado. 2005. Conservation of the Brazilian Cerrado. Conserv. Biol. 19: 707-713.

Larcher, W. 2000. Ecofisiologia vegetal. Editora RIMA, São Carlos, São Paulo, Brasil.

Laurance, W.F., L.V. Ferreira, J.M. Rankin-de-Merona \& S.G. Laurance. 1998. Rain forest fragmentation and the dynamics of Amazonian tree communities. Ecology 79: 2032-2040.

Laurance, W.F., T.E. Lovejoy, H.L. Vasconcelos, E.M. Bruna, R.K. Didham, P.C. Stouffer, C. Gascon, R.O. Bierregaard, S.G. Laurance \& E. Sampaio. 2002. Ecosystem decay of Amazonian forest fragments: a 22-year investigation. Conserv. Biol. 16: 605-618. 
Mani, M.S. 1964. Ecology of plant galls. Dr. W. Junk, The Hague, Holland.

Meiners, S.J., S.N. Handel \& T.A. Pickett. 2000. Tree seedling establishment under insect herbivory: edge effects and interannual variation. Plant Ecol. 151: 161-170.

Moreira, R.G., G.W. Fernandes, E.D. Almada \& J.C. Santos. 2007. Galling insects as bioindicators of land restoration in an area of Brazilian Atlantic Forest. Lundiana 8: 107-112.

Murcia, C. 1995. Edge effects in fragmented forests: implications for conservation. Trends Ecol. Evol. 10: 58-62.

Nascimento, H.E.M. \& W.F. Laurance. 2006. Efeito de área e de borda sobre a estrutura florestal em fragmentos de floresta de terra-firme. Acta Amaz. 36: 183-192.

Nepomuceno, A.L., N. Neumaier, J.R.B. Farias \& T. Oya. 2001. Tolerância à seca em plantas. Biotec. Ciência Desenvol. 23: 12-18.

Nieves-Aldrey, J.L., A. Ibáñez \& E. Medianero. 2008. Richness and composition of gall-inducing arthropods at Coiba National Park, Panama. Rev. Biol. Trop. 56: $1269-1286$.

Paciencia, M.L.B. \& J. Prado. 2004. Edge effects on pteridophyte community in Atlantic rain forest of the Una region, South of Bahia State, Brazil. Rev. Bras. Bot. 27: 641-653.

Price, P.W. 1991. The plant vigor hypothesis and herbivore attack. Oikos 62: 244-251.

Price, P.W., G.W. Fernandes \& G.L. Waring. 1987. Adaptive nature of insect galls. Environ. Entomol. 16: 15-24.

Price, P.W., G.W. Fernandes, A.C.F. Lara, J. Brawn, D. Gerling, H. Barrios, M. Wright, S.P. Ribeiro \& N.
Rothcliff. 1998. Global patterns in local number of insect galling species. J. Biogeog. 25: 581-592.

Ribeiro, S.P., Carneiro, M.A.A. \& Fernandes, G.W. 1998. Richness and distribution of free-feeding insect herbivores in Serra do Cipó, an old quartzite Brazilian mountain. J. Insect Conserv. 2: 1-12.

Ribeiro, S.P. \& G.W. Fernandes. 2000. Interações entre insetos e plantas no Cerrado: teoria e hipóteses de trabalho, p. 299-320. In R.P. Martins, T.M. Lewinsonn \& M.S. Barbeitos (eds). Ecologia e comportamento de insetos. Serie Oecologia Brasiliensis, vol. VIII, Rio de Janeiro, Rio de Janeiro, Brasil.

Santos, B.B., H.D. Ferreira \& W.S. Araújo. 2010. Ocorrência e caracterização de galhas entomógenas em uma área de floresta estacional semidecídua em Goiânia, Goiás, Brasil. Acta Bot. Bras. 24: 243-249.

Shorthouse, J.D., D. Wool \& A. Raman. 2005. Gall-inducing insects - nature's most sophisticated herbivores. Basic Appl. Ecol. 6: 407-411.

Souza, V.C. \& H. Lorenzi. 2005. Botânica Sistemática: Guia ilustrado para identificação das famílias de Angiospermas da flora brasileira, baseado em APG II. Editora Plantarum, Nova Odessa, São Paulo, Brasil.

Stone, G.N. \& K. Schönrogge. 2003. The adaptive significance of insect gall morphology. Trends Ecol. Evol. 18: $512-522$.

Veldtman, R. \& M.A. McGeoch. 2003. Gall-forming insect species richness along a non-scleromorphic vegetation rainfall gradient in South Africa: the importance of plant community composition. Austral Ecol. 28: 1-13.

White, T.C.R. 2009. Plant vigour and plant stress: a false dichotomy. Oikos 118: 807-808. 
